\title{
Resource Tax Research Based on Resource Price Optimization
}

\author{
Hongmei Ye \\ Xi’an International University, Xi'an, Shaanxi 710077
}

Keywords: resource tax, resource price optimization, resource management

\begin{abstract}
After years of reforming the economic system and breaking through the dilemma of the system, a series of unsuccessful areas of rapid development is left, bringing great achievements in economic construction and causing the bottleneck effect of resource constraints to become more and more difficult. The unscientific factor price formation mechanism and the unreasonable price comparison of resource products have become an important reason for the current deforestation, overuse and vandalism of resources and energy, and also an institutional obstacle to the transformation of China's economic development mode. It is an urgent and arduous task of the times to make the prices of resource products such as coal, oil, gas, water and minerals reasonable. It is also an important focus of this paper. It focuses on the macro-control role of fiscal and taxation policies, and takes resource tax reform as the starting point. The aim is to clarify the taxation relationship in the field of natural resources by reforming resource taxes to achieve the goal of optimizing the prices of resource products.
\end{abstract}

\section{Introduction}

Natural resources are the material basis on which human beings depend. The development of human beings is inseparable from the consumption of resources. The exploitation, distribution and use of resources will have a tremendous impact on all fields of society. Although the total amount of natural resources in China is relatively large, the varieties are relatively complete, but the per capita possession of resources is small. The per capita possession of freshwater resources, per capita arable land, per capita forest area and most major mineral resources is far below the world average. In recent years, with the sustained and rapid development of China's economy, the growing demand for resource products and the contradiction between limited resources and scarcity have become increasingly prominent. The resource tax system based on the quantitative quota is difficult to fully play its role in regulating the distribution of resource benefits, reflecting the exploitation of resources, limiting resources, and promoting resource conservation. To this end, on the basis of the reform of the crude oil natural gas, coal, rare earth, tungsten and molybdenum resource tax ad valorem, the resource tax reform will be comprehensively promoted from July 1, 2016, except for a small amount of taxable mineral products. In addition, the ad valorem levy is fully implemented, the scope of tax collection is expanded, the compensation for mineral resources is abolished, and the taxation and fee shift is implemented, and the tax rate is uniformly set by the central government. However, from the perspective of reform effectiveness, there is still a big gap between the goals of innovation, coordination, green, openness and sharing. Then, in the current process of accelerating the resource tax legislation, how to re-orientate the role of resource taxation in a scientific way? Where is the legislative implementation path and program design path?

\section{Theory of Resource Tax}

The theory of sustainable development is a scientific choice made by human beings after pondering the progress of their own civilization. It represents a scientific development model. The concept of sustainable development transforms the development model of purely pursuing economic growth and neglecting ecological environmental protection into a multi-faceted factor that takes into account economic growth, social stability, environmental tolerance, intergenerational appeals, etc., by promoting industrial restructuring and upgrading, and economic development 
model renewal. To achieve harmony between mankind and nature, between the present and future generations. The sustainable development theory has a profound connotation. One of the important contents is: Comprehensive consideration of social, economic, resource and environmental benefits, achieving balanced development of multi-party appeals, and gradually shifting the economic development model from resource-based to technical. Sustainable development is an inevitable requirement for the construction of ecological civilization and the result of ecological civilization construction. China's economy is growing rapidly, the contradiction between supply and demand of natural resources has become more and more prominent, and the fragile ecological environment is increasingly unable to carry huge demand for resources. Resource tax is a powerful lever for the government to carry out economic regulation and control, and can play a huge role in promoting energy conservation and promoting sustainable economic and social development. The government can guide the transformation of social capital from depleted energy products to energy-saving energy products through resource taxes, and promote the efficiency of resource extraction and utilization. At the same time, it is also possible to use the tax total adjustment function to achieve a relative balance of the effective supply of resources in China in the future.

The theory of public goods is a basic theory of new political economy, and it is also the basic theory of correctly handling the relationship between government and market, the transformation of government functions, the construction of public revenues and expenditures, and the marketization of public services. The theory divides social products into public and private products. According to Samuelson's definition of "Pure Theory of Public Expenditure", pure public goods or services are products or services that consume no such goods or services for everyone. Reduction. Moreover, public goods or services have three characteristics that are significantly different from private products or services: the indivisibility of utility, the non-competitiveness of consumption, and the non-exclusiveness of benefits. Following the utility-cost-tax program, taxation becomes the "tax price" of public goods, which is the price that people pay for public goods and services, thereby linking the costs and charges of public goods supply organically. According to the market economy and public product theory, the government must not only provide the necessary external conditions for the operation of the market economy, but also play a role in filling, correcting and regulating the gaps in the market economy. The government has become the center of public economic activity, providing more and more public goods and services to the society. The activities of fiscal revenue collection and distribution of expenditures are no longer a general distribution, but also provide public goods and services for the society, and adjust the allocation of resources and market demand.

\section{Status of China's Resource Tax and Fee}

China's current resource taxes and fees are mainly levied on mineral resources. In addition to general taxes and fees, units engaged in mineral resources exploration and mining are also required to pay special taxes on mineral resources, including: exploration rights, mining rights, and prospecting. The right to use mining rights, resource taxes and special oil revenues. The exploration rights and mining rights price refers to the income obtained by the state when it transfers the exploration rights and mining rights of the mineral deposits to the relevant units and individuals, and is divided into two types: exploration price and mining price. It is based on the evaluation of the value of mineral resources, and is determined by the market competition mechanism through bidding, auction, listing, etc., and the rents that reflect the rights and interests of the state owners are paid once or in installments. The exploration right of mining rights is essentially the rent of the mine. It is the rent paid by the relevant units and individuals for mining minerals in the mineral exploration and mining activities. It is divided into the exploration rights and the mining rights. class. The royalties of exploration rights and mining rights are collected annually according to the area of the mining area occupied. It regulates resource exploration and mining activities, avoiding "staking the land" and leaving the land unused. Including water resources fees, sewage charges, forest vegetation restoration fees, grassland vegetation restoration fees, soil and water conservation compensation fees, land reclamation fees, etc. The water resource fee change tax was implemented in Hebei Province on July 1, 2016, and the water resource tax was levied. The water resource fee 
rate will be reduced to zero, and the sewage charge will be changed to environmental protection tax. China's resource tax and fee system has played a positive role in safeguarding the country's property rights and interests in mineral resources, safeguarding and promoting the exploration, protection and rational development and utilization of mineral resources, promoting the development of the national economy and environmental ecology, and also laying the ground for the mining of mineral resources in China. system. In theory, the composition of the resource tax and fee system does not have a so-called maturity or target model, that is, each country formulates and forms a specific resource tax and fee system according to their actual national conditions. As long as the tax and fee system can achieve the goal that the state wants to achieve, can.

\section{Function Positioning of Resource Tax}

In terms of taxation, it mainly has the functional role of both income and regulation. With the constant changes in the market environment of resource products, economic externalities such as environmental pollution caused by resource exploitation are also constantly emerging. The new situation puts new demands on the taxation function and role of resource tax, and requires it to adapt to the economy. Make due contributions to sustainable development and protection of the ecological environment. The "Overall Plan for the Reform of Ecological Civilization System" requires: "To improve the system of paid use of resources and ecological compensation. Accelerate the reform of resources, taxes and fees. Rationalize the relationship between natural resources and their products, clear their respective functions, and rationally determine the scope of tax regulation." Therefore, the resource tax legislation should achieve the following functions on the basis of summarizing the existing resource tax system and learning from the experience and enlightenment of foreign resource tax. Resource conservation is the fundamental national policy to protect the ecological environment. The development and utilization of natural resources such as forests and grasslands is also one of the contents of ecological environmental protection. Restoring the ecological environment damage caused by the exploitation and utilization of mineral resources and other sources also promotes ecological environmental protection. From the current point of view, the ecological environment management and compensation for resource exploitation are not enough. The resource enterprises have not implemented the corresponding governance and compensation responsibilities according to the principle of "who pollutes, who governs, who destroys, who recovers, who uses, and who pays". The funds raised are restored by the state, and the overall use efficiency is not high, and it is difficult to meet the requirements of ecological environment restoration and governance. Therefore, resource taxes also need to play a role in ecological environmental protection. The resource tax legislation can not only ensure the implementation of the ecological compensation nature fee and deposit system, but also increase the environmental cost of developing and utilizing natural resources through resource taxes, and raise income for ecological environment management.

\section{Policy Recommendations for Resource Tax Reform}

Expanding the current scope of resource taxation has basically become a consensus on resource tax reform. Through the introduction of some typical resource taxation in foreign countries and the current status of China's current resource tax system, we have clearly felt that the scope of China's resource taxation is too narrow. Regarding resource taxes, there are basically three types of understanding of large resource taxes, medium resource taxes, and small resource taxes, depending on the difference in scope. Large resource tax refers to the comprehensive collection of all renewable and non-renewable resources, and the creation of resource tax as the main tax. This kind of thinking is very reflected in Rao Lixin's works. He is quite sure of the necessity and feasibility of building the resource and environmental tax into the third main tax category in China. The view of China's resource tax is limited to the collection of non-renewable resources and renewable but vulnerable resources. The small resource tax does not require further expansion of the scope of taxation, but should strengthen the level adjustment of mineral resources. As far as China's current 
situation and tax maturity are concerned, if it is possible to realize the big resource tax, it is only a long-term goal. However, the small resource tax does not seem to have much change in China's current resource tax, and its protection resources. The functionality will also be limited. This paper believes that as far as China's current situation is concerned, China's resource tax should be the direction of resource tax reform, which is both necessary and feasible.

Reasonable resource product prices are the basis for the healthy development of an economy. The strong planning color in the resource field has caused the normalization of resources in China. Although the state has taken measures to restrict the export of primary products, the arbitrage market is still widespread. Especially in the current situation of many state-owned enterprises in the field of mineral resources, with the overseas listing of monopoly state-owned enterprises, the low-cost dividends for the resources of China's national wealth have been drawn by foreign investors. Therefore, the implementation of ad valorem taxation in the field of resources, the establishment of a reasonable tax burden, through the role of tax leverage, change the resource is near priceless, the raw material is significantly lower than the current situation, the formation of relatively reasonable resource product prices, is a national interest Rational choice.

\section{Conclusion}

With the advancement of the country's legalization process and the increasingly fierce call for taxation, the legislative reform of resource tax is imperative. This paper tries to analyze the law of China's resource economy operation, objectively summarizes the experience of previous resource tax reforms, and draws on the advanced experience and practices of international resource tax. Redefine the positioning of resource tax function. On this basis, it proposes the implementation path and scheme design of resource tax legislation, so as to establish a resource tax system with standardized fairness, reasonable regulation, and efficient collection and management, and build a "green" tax system to promote environmental protection and rational development and utilization. Natural resources, promote green production and consumption, and achieve sustainable economic and social development.

\section{References}

[1] Chen Wendong. Research on several issues of resource tax and fee reform [J]. Journal of Central University of Finance and Economics, 2013 (10).

[2] Yin Aizhen, Li Linfang. Research on the reform of mineral resources tax and fee system in China [J]. Financial Market, 2011 (8).

[3] Ma Changhai, Liu Mengyan. Resource Tax Target Positioning and System Optimization [J]. People's Forum, 2013 (5).

[4] Gong Wanda. Resource Endowment and Regional Economic Development [J]. Journal of Sichuan Administration College, 2010 (2).

[5] Feng Wei, Jiao Yanbin, Zhang Shanming, Zhu Zhezhen. Discussion on the reform of mineral resources tax and fee [J]. Resources and Industry, 2013 (2). 